\title{
Discourses of Division: Law, Politics and the ICJ Advisory Opinion on the Legal Consequences of the Construction of a Wall in the Occupied Palestinian Territory
}

\author{
Michelle Burgis*
}

\begin{abstract}
This article undertakes a critical reading of the arguments used at the bench and the bar in the 2004 ICJ Wall advisory opinion. The Wall case included an unprecedented number of State and non-State participants and it is therefore a valuable site in which to explore the parameters and limits of legal speech. What argumentative strategies were employed at the Peace Palace? How did different participants present the relationship between law and politics? In particular, because the example of Palestine can be seen as a challenge to the post-colonial order, how did Third World States employ the language of international law in support of Palestinian self-determination? It is shown that although international legal speech is highly restrictive, many Third World States are willing to challenge its boundaries through a deep-set faith in the dividends of legal argumentation.
\end{abstract}

\section{Introduction}

1. The International Court of Justice's (ICJ) 2004 advisory opinion ${ }^{1}$ on Israel's "security" wall has elicited widespread comment within academic and policy circles. This is not

* $\mathrm{BA}($ Hons)/LLB(Hons) (University of Sydney), PhD Candidate, Regulatory Institutions Network, Australian National University (email: michmich78@gmail.com). This article forms one of four case studies in the author's PhD thesis entitled, "Boundaries of Discourse in the International Court of Justice: Mapping Arguments in Arab Territorial Disputes". Thanks to Hilary Charlesworth and John Braithwaite for their comments and support. The final version of this paper was completed on 22 November 2007.

1 ICJ Reports 2004, 136, hereinafter the Wall Opinion, or the Opinion. 
surprising given the issues raised in the case and the passions aroused from the broader Arab-Israeli conflict. Attention in particular has focussed on the Court's application of international humanitarian law and human rights law to the Occupied Palestinian Territories. This article is not another exploration of these issues. Instead, the following discussion returns to the United Nations Headquarters and particularly the Peace Palace to look at the dialogue that took place between States, international organizations and the Court. Few commentators have probed the written and oral statements of the case itself, but it is argued here that such material is a rich resource to explore issues of international law's legitimacy and relevance in a post-colonial era. The example of Palestine encapsulates many of the fundamental legal elements in this era after colonialism, including self-determination, neocolonialism, conquest and the application and role of international law. How were these ideas explored by participants? More importantly, this article examines the different discursive techniques used by First and Third World States in presenting their respective visions of international law in a post-colonial era. What is the role of law in resolving colonial struggles and how was the colonial past linked to the colonial present in the case of Palestine?

2. With a wide array of arguments employed, the Wall case allows us to map discursive strategies used to extrapolate the relationship between international law and politics. Several States presented either written submission or oral presentations both supportive and dismissive of the Court's role in adjudicating Israel's construction of a wall in Palestine and its legal effects. States opposing the ICJ's jurisdiction saw the United Nations General Assembly's (UNGA) request for an opinion as politically driven. The Court could not fulfil its role in such a context and further, it would hamper other initiatives. Supporters of the Court, on the other hand, were required to leave their politics at the courtroom door. By backing ICJ jurisdiction, these mostly Third World States suggested that the Peace Palace could be quarantined from politics. The Court itself was also conscious of the political significance of the matter, and thus this case is a valuable site for exploring different characterizations of international law and its relationship with politics. The UNGA advisory opinion question to the Court was circumscribed, but both States and members of the Court touched on broader, "political" considerations of the Arab-Israeli conflict. In particular, the importance of selfhood and territory informed many positions. Thus, the Wall Opinion can be seen as a classic (post)colonial contest over international legal personality: in a world of nationstates, securing territory is vital.

3. This article explores some of the substantive claims made by States and the Court by looking at the discursive techniques employed throughout the case. Rather than examining contests over legal rules per se, this article contrasts and compares the articulation of international law as a discourse. A wide range of images, narratives and perspectives indicate that international adjudication is about much more than the contest over legal rules. It is a constant negotiation about the boundaries of international legal discourse and its relationship with politics. Where were the boundaries drawn between law and politics in the Wall case and to what extent can we identify patterns of argument in such efforts? In particular, the paper explores the imagery used in the pleadings to map out the argumentative synchronies amongst Third World, and especially, Arab, States. 
4. The article begins with a brief overview of the Arab-Israeli conflict as well as the UNGA request to set the backdrop for discursive difference between the UN headquarters setting and the Peace Palace. The Court's judgment is then summarized before turning to the images employed, arguments invoked about jurisdiction and some substantive claims raised in the case. The Wall case is about much more than the Court's judgment and its reception; it is a particularly rich example of international law as a discourse of ongoing articulation and negotiation.

\section{Background to the opinion}

\section{II.A. Brief overview of the Arab-Israeli conflict}

5. After four wars, ${ }^{2}$ two peace treaties, ${ }^{3}$ innumerable diplomatic initiatives and the Israeli occupation of the Palestinian West Bank and Gaza Strip as well as parts of Syria, Egypt and Lebanon, ${ }^{4}$ the Arab-Israeli conflict remains far from resolved. Its complexity and the passions it arouses have prevented international law from playing a central role and yet the conflict spans a number of seminal international legal issues, many of which were explored in the Wall advisory opinion. ${ }^{5}$

6. As a result of 40 years of Israeli occupation, Palestine's fortunes have always been linked not only with its occupier, but international institutions and international law as well. Further, the narrative of Palestine contains many central themes in post-colonial accounts of international law during the modern period. Although the end of World War I had ushered in a powerful discourse supportive of self-determination, this was only applicable to European peoples. Yet, "Ottoman military defeat by the British and French during the First World War produced a radical change throughout the whole Middle East", ${ }^{6}$ including calls for an independent homeland. Secret treaties signed during the war assured French and British interests. ${ }^{7}$ The realization of these agreements did not produce typical colonial administrations, but the League of Nations Mandate, "which was used to legitimise British and French government of their Middle East possessions". ${ }^{8}$ During the war, Britain also assured the interests of its national Zionist lobby. Through the efforts of the

2 Namely, the 1948 War, the Suez Canal Crisis 1956, the Six Day War of 1967 and the Yom Kippur War of 1973.

3 Between Israel and Egypt in 1979 and between Jordan and Israel in 1994.

4 The West Bank and Gaza in Palestine, Syria's Golan Heights and Egypt's Sinai Peninsula were occupied after the Six Day War of 1967 and all but the Sinai remain under Israeli occupation. Southern Lebanon was occupied by Israel between 1982 and 2000.

5 Crawford argues that the bulk of international law literature on the conflict has been "violently partisan", James Crawford, Israel (1948-1949) and Palestine (1998-1999): Two Studies in the Creation of States, in Guy S. Goodwin-Gill and Stefan Talmon (eds), The Reality of International Law: Essays in Honour of Ian Brownlie (1999) (Oxford: Clarendon Press, 1999) 95-124.

6 Roger Owen, State, Power and Politics in the Making of the Modern Middle East (London: Routledge, 2nd edn. 2000) 9.

7 Namely, the Sykes-Picot Agreement: Exchange of Letters between France and Great Britain respecting the Recognition and Protection of an Arab State in Syria, 9/6 May 1916, 221 CTS 323; and Exchange of Notes between France and Great Britain modifying the Agreement of 9/6 May, 25/30 May 1916, 222 CTS 13.

8 Owen, above n. 6, 8. 
Zionist Federation in Britain, the Cabinet endorsed a statement drafted by the Federation's leaders. ${ }^{9}$ This document, which came to be known as the 1917 Balfour Declaration, noted that Britain "viewed with favour the establishment in Palestine of a national home for the Jewish people, it being clearly understood that nothing should be done which might prejudice the civil and religious rights of existing non-Jewish communities in Palestine". ${ }^{10}$ Crawford argues that it remains unclear whether Britain's responsibilities under the League Covenant should have precluded its support of Jewish interests and whether it really was possible to juggle such competing interests. ${ }^{11}$ What at least is clear is that Britain was unable to resolve this tension and that the seeds of conflict can be traced to the fundamental incompatibility between mandate responsibilities contained in Article 22 of the League Covenant and the Balfour Declaration. ${ }^{12}$

7. Until Britain's withdrawal from Palestine in 1948, tensions between Jewish and Arab populations had produced not only serious local tensions but also international attention from the newly formed UN. As the Arab League remarked in its oral statement in the Wall advisory opinion, the "issue of Palestine is the longest-lived problem on the agenda of the United Nations". ${ }^{13}$ Despite the formation of dedicated committees overseeing Palestine's future as well as a General Assembly-endorsed Partition Plan, ${ }^{14}$ disagreement was so pronounced that war broke out between Jewish and Arab forces soon after Britain's flight from mandatory responsibility. The international consequences of this war

9 John Quigley, The Case for Palestine: An International Law Perspective (Durham; London: Duke University Press, revised, 2005) 8.

10 Quoted in Quigley, ibid.

11 Crawford (1999), above n. 5, 104-106.

12 Article 22 of the League Covenant states:

To those colonies and territories which as a consequence of the late war have ceased to be under the sovereignty of the States which formerly governed them and which are inhabited by peoples not yet able to stand by themselves under the strenuous conditions of the modern world, there should be applied the principle that the well-being and development of such peoples form a sacred trust of civilisation and that securities for the performance of this trust should be embodied in this Covenant.

The best method of giving practical effect to this principle is that the tutelage of such peoples should be entrusted to advanced nations who by reason of their resources, their experience or their geographical position can best undertake this responsibility, and who are willing to accept it, and that this tutelage should be exercised by them as Mandatories on behalf of the League.

The character of the mandate must differ according to the stage of the development of the people, the geographical situation of the territory, its economic conditions and other similar circumstances.

Certain communities formerly belonging to the Turkish Empire have reached a stage of development where their existence as independent nations can be provisionally recognized subject to the rendering of administrative advice and assistance by a Mandatory until such time as they are able to stand alone. The wishes of these communities must be a principal consideration in the selection of the Mandatory.

For an overview of the difficulties faced in honouring the Balfour Declaration under the Mandate, see Ilan Pappé, A History of Modern Palestine: One Land, Two Peoples (Cambridge University Press, 2004), chapter 3.

13 Michael Bothe, Oral Statement of the League of Arab States, 25 February 2004, CR 2004/5, at 22 (www. icj-cij.org/docket/files/131/1521.pdf).

14 The Partition Plan was included within Resolution 181(11), 29 November 1947. For a general overview of the events precipitating the 1948 war, see John Quigley, Sovereignty in Jerusalem, 45 Catholic University LR (1996) 765 , at $769-771$. 
included the creation of the State of Israel; ${ }^{15}$ agreement on the 1949 Armistice Line (often referred to as the Green Line) dividing Israel from the Jordanian-administered West Bank; a large mass of Arab refugees ${ }^{16}$ who would come to rest their hopes increasingly on the promise of self-determination rather than the lukewarm reception by Arab states; as well as the seeds of deep-set animosity between Israel and its Arab neighbours.

8. Regional tensions came to their climax in the 1967 war. After only six days, the war ended with the Israeli occupation of territories east of the Green Line (including East Jerusalem), as well as the Golan Heights in Syria and Egypt's Sinai Peninsula. Almost immediately after the occupation of Palestinian lands, Israel's actions were condemned by the UN Security Council (UNSC) in Resolution $242 .{ }^{17} \mathrm{UN}$ resolutions following the conflict accepted the cease-fire lines (including the "Green Line" delimiting the West Bank), but rejected the "conferring of any title to the territory occupied by Israel". ${ }^{18}$ Since 1967, Palestine has remained a central concern of the UN, and yet independence is as elusive now as it was with the creation of the Mandate. Both the UNGA and the UNSC have issued countless resolutions on specific aspects of the conflict, and the central themes to emerge from these include: the Palestinian right to self-determination, the non-recognition of Israeli sovereignty over the territory and its status instead as a belligerent occupier under the ambit of international humanitarian law, the importance of regional peace agreements, the illegality of Israeli settlements and the need for both Palestinians and Israeli to cease the cycle of violence perpetrated by both public and private actors against civilians. ${ }^{19}$

9. In 2002, only a year before the UNGA requested the Court's assistance, the Roadmap was first mooted as a way of ameliorating regional tensions. The Roadmap laid out steps to be followed by Palestine and Israel and it was overseen by the UN, the United States (US), the European Union (EU) and Russia. These four actors came to be known as the Quartet and they continued to support the Roadmap throughout the advisory opinion proceedings. ${ }^{20}$

15 Israel also became a member of the United Nations on 11 May 1949 as a result of General Assembly Resolution 273 (III). The territory comprising the new State of Israel was much larger than that envisaged under the UN 1947 Partition Plan and so some Arab States in their Wall Opinion submissions argued that Israel's UN membership must be based on its compliance with the territorial plans of the partition. UN membership, however, is not conditional and Crawford points out (above n. 5, at 108-110) that the best explanation for Israel's formation was as an act of force leading to secession (requiring stable and effective government). Israel would have been able to demonstrate this capacity by January 1949.

16 Halliday suggests that the figure was around 1.4 million. Fred Halliday, The Middle East in International Relations: Power, Politics and Ideology (Cambridge: Cambridge University Press, 2005) 94.

1722 November 1967.

18 Q. Wright, The Middle East Problem, 64 AJIL (1970), 270, 272.

19 For an extensive list of UN resolutions on Palestine visit www.arableagueonline.org/las/english/ level2_en.jsp?level_id=701.

20 For some background about the Roadmap, see International Crisis Group, Report N.14, A Middle East Roadmap to Where?, 2 May 2003, (www.crisisgroup.org/home/index.cfm?id=1659\&l=1). The Roadmap was endorsed by the UNSC in Resolution 1515, 19 November 2003: S/RES/1515 (2003). 
10. Palestine's occupation was characterized by many Third World States in the Wall pleadings as a form of colonialism in a post-colonial era. Post-colonial states, in particular, have employed the language of international law in the cause of Palestinian self-determination, which suggests that international law is being used as a weapon of the weak in their attempt to solidify a world free of colonialism. ${ }^{21}$ Whether international law as a body of norms is capable of supporting such aims is the subject of discussion below.

\section{II.B. Bringing the conflict before the Court: the request for an advisory opinion}

11. Although Palestine has been a constant on the agendas of the UNGA and UNSC, it was not until Israel's construction of a wall, that the UNGA sought the assistance of the ICJ. Only the UNSC, UNGA or specialized UN bodies acting within the scope of their mandate can request an advisory opinion from the Court. ${ }^{22}$ Under the Charter, the power of the UNGA to make a request is further limited by Article 24, which establishes that the UNSC has "primary responsibility for the maintenance of international peace and security". Although this provision can be read as prohibiting all UNGA involvement in affairs under the Council's consideration, Article 24 stipulates only "primary responsibility". ${ }^{23}$ Further, in 1950, the UNGA passed its "Uniting for Peace" resolution, which provides that

if the Security Council, because of lack of unanimity of the permanent members, fails to exercise its primary responsibility for the maintenance of international peace and security in any case where there appears to be a threat to the peace, breach of the peace, or act of aggression, the General Assembly shall consider the matter immediately with a view to making appropriate recommendations to members for collective measures ... If not in session at the time, the General Assembly may meet in emergency special session within twenty-four hours of the request therefor. ${ }^{24}$

12. The 10th Emergency Special Session had been convened in 1997 to discuss Israeli settlements in the Occupied Palestinian Territories after a veto by the US in the Security Council. ${ }^{25}$ The 10th Session was reconvened on 20 October 2003 in the wake of another US veto of a Council Resolution, which was partially concerned with the construction of a wall in the Occupied Palestinian Territories. ${ }^{26}$

21 Power disparities were illustrated in Professor Salmon's speech on behalf of Palestine: "Advocating negotiations between the wolf and the lamb implies ensuring minimum protection for the lamb". Oral Statement of Palestine, 59, 23 February 2004, CR 2004/1, para. 7 (translation) (www.icj-cij.org/docket/files/131/1505.pdf).

22 Under Article 96 of the United Nations Charter and Article 65 of the Statute of the International Court of Justice.

23 This is discussed by the Court in the Wall Opinion: I.C.J. Reps (2004), para. 24.

243 November 1950, 377(V).

25 For resolutions passed on this issue in the session, see A/RES/ES-10/2, 5 May 1997; A/Res/ES-10/3, 30 July 1997; A/RES/ES-10/4, 19 November 1997.

26 Draft Resolution S/2003/980, 14 October 2003. 
13. The minutes from the Emergency Special Sessions preceding the advisory opinion pleadings indicate that positions about the Court's role in the case and the legal issues raised were already clearly established. Many UN member states that spoke during the 2003 special sessions also went on to present submissions to the Court and there is very little internal discrepancy in their arguments. ${ }^{27}$ Although stances on legality or illegality and the applicable law used remained relatively constant, there was a significant shift in the language and imagery used in the two settings. Speaking before fellow UN members in a highly charged political setting, speakers were more confident in employing "inflammatory" language that often verged on the excessive. ${ }^{28}$ Speakers in the UN setting also appeared more confident about using or abusing international law for their own partisan purposes. ${ }^{29}$ The use of legalese was rare and it would seem that the atmosphere of the Court produced a marked difference in the behaviour of participants. These observations suggest that States regard the practice and discourse of international law argued before the ICJ as qualitatively distinct from the political setting of the UNGA.

14. After heated debate, a number of resolutions were passed about the wall's construction and the scope for requesting an advisory opinion. In Resolution ES-10/13 calling for Israel to "stop and reverse the construction of the wall in the Occupied Palestinian Territory, including in and around East Jerusalem" as well as report by the Secretary-General on Israel's compliance, ${ }^{30} 144$ States supported the Resolution with 4 against and 12 abstaining. ${ }^{31}$ Shortly after the Secretary-General's report was received and after the Council veto, Kuwait on behalf of the Arab group as well as Malaysia on behalf of the Non-Aligned Movement (NAM) sought the reconvention of the Session to respond to the report's findings. The various references made to the Arab and NAM positions throughout the meetings suggest a mutual position not only about the wall's illegality, but also the need for an advisory opinion. ${ }^{32}$ In this vein and after much hyperbole, a resolution requesting the Court's advisory opinion was put to the vote and passed. Like other earlier resolutions, Resolution ES 10/14 condemned the wall's construction. ${ }^{33}$ Its call for the Court's intercession, however, aroused caution in many-particularly

27 For ease of expression, "States" will be used to denote State, as well as quasi-state entities (such as Palestine) where I am discussing general UN activities by its member States and permanent observers.

28 In the words of the President of the 26th Emergency Special Session, "I really want to caution against the language being used in matters that are ticklish debates which sometimes have the tendency of being inflammatory and not necessarily helping the cause. I really want to make it clear, that for whatever reason - and I do not really care who is upset - I really object to any analogy that is made, particularly from the inside, which may have a tendency to describe as in the Assembly as inmates in an asylum. I think that we can find better language to use in terms of describing the debates that are taking place here". E/ES-10/PV.26, 19 July 2004, 3.

29 For example, "it is abundantly clear that the construction of the expansionist annexation wall by the occupying Power is a war crime and, I reiterate, a war crime of such seriousness and intensity that it constitutes a crime against humanity". Mr M. Nasser Al-Kidwa, UN Observer of Palestine, A/ES-10/PV.21, 20 October 2003, 3.

30 A/RES/ES-10/13, 27 October 2003.

31 A/ES-10/PV.22, 21 October 2003, 2-3.

32 Generally see A/ES/10/PV.23, 8 December 2003.

33 A/RES/ES-10/14, 12 December 2003. 
European-States and the resolution passed with a smaller majority (111, with 55 abstentions and 7 against). ${ }^{34}$ Despite this, numbers were sufficient in transferring the debate from New York to The Hague. ${ }^{35}$

\section{The Decision of the Court ${ }^{36}$}

15. In its resolution, the UNGA had asked the Court to give its advice on the following question:

What are the legal consequences arising from the construction of the wall being built by Israel, the occupying Power, in the Occupied Palestinian Territory, including in and around East Jerusalem, as described in the report of the Secretary-General, considering the rules and principles of international law, including the Fourth Geneva Convention of 1949, and relevant Security Council and General Assembly resolutions? ?7 $^{37}$

16. The Court provided its response in the form of an Opinion as well as a number of separate opinions and one dissenting declaration. ${ }^{38}$ Its treatment of jurisdiction, propriety and the merits are considered in turn.

\section{III.A. Jurisdiction}

17. The Court's jurisdiction was challenged on a number of grounds. First, the Court had to consider whether the Emergency Special Session request was valid. The Court accepted the nexus between the Uniting for Peace Resolution and the UNGA's request and went on to hold that there were no reasons to regard the request as invalid. ${ }^{39}$ Secondly, a number of submissions characterized the UNGA request as insufficiently "legal" as per Article 96 of the Charter; ${ }^{40}$ that the request lacked clarity; and that it was too political. The Court drew on

34 A/ES/10/PV.23, 8 December 2003, 20-21.

35 It must be pointed out that this was not the first ICJ case dealing with Palestine. Others include: Reparation for Injuries Suffered in the Service of the United Nations, advisory opinion, ICJ Reports 1949, 174; and the United Nations Headquarters Agreement of 26 June 1947, Advisory Opinion, ICJ Reports 1988, 12.

36 For a summary of the case, see Pieter H.F. Bekker, The World Court Rules that Israel's West Bank Barrier Violates International Law, ASIL Insights, July 2004, Susan C. Breau, Legal Consequences of the Construction of a Wall in the Occupied Palestinian Territory: Advisory Opinion, 9 July 2004, 54 ICLQ (2005), 1003; Noam Lubell, The ICJ Advisory Opinion and the Separation Barrier: A Troublesome Route, 35 Israel YB Human Rights, 283; and Nicolaos Strapatsas, Case Note on the ICJ Advisory Opinion on the Legal Consequences of the Construction of the Wall in Occupied Palestinian Territory, 35 Israel YB Human Rights (2005), 251.

$37 \mathrm{~A} / \mathrm{RES} / \mathrm{ES}-10 / 14$, at 3.

38 Judges Koroma, Higgins, Kooijmans. Al-Khasawneh, Elaraby and Owada issued separate opinions; and Judge Buergenthal issued a dissenting declaration.

39 ICJ Reports 2004, para. 35.

40 Article 96 states: "The General Assembly or the Security Council may request the International Court of Justice to give an advisory opinion on any legal question". 
its jurisprudence to show that none of the objections raised were grounds for declining jurisdiction. ${ }^{41}$ It held that the request centred on a sufficiently legal matter. ${ }^{42}$ For Judge Koroma, the question was "eminently legal". ${ }^{3}$ The Court was not concerned that the wording of the request was somewhat vague as it pointed out that such a situation simply required "clarification in interpretation, and such necessary clarifications have frequently been given by the Court". ${ }^{44}$ Lastly, "the Court cannot accept the view ... that is has no jurisdiction because of the 'political' character of the question". 45 The Opinion relied on ICJ decisions, especially Legality of the Threat or Use of Nuclear Weapons, ${ }^{46}$ to rebut this argument. ${ }^{47}$ The Court acknowledged the existence of politics in its work, but maintained that politics and many other issues were inherent aspects of international law and did not negate the quality of the legal question under consideration. Accordingly, the Court found it had jurisdiction to give the requested advisory opinion. ${ }^{48}$ The Court may have acknowledged the political context, but its judgment on the merits demonstrated how it strove to overlook tensions beyond the courtroom. As is typical in ICJ cases, the language of the Opinion was used to avoid many of the complexities highlighted from a reading of the pleadings.

\section{III.B. Propriety}

18. Although the Court affirmed its jurisdiction, it also considered whether there were elements of the UNGA's request "that would render the exercise of the Court's jurisdiction improper and inconsistent with the Court's judicial function". ${ }^{49}$ A substantial body of jurisprudence has grown up around this question, which generally focuses on whether there would be any "compelling reasons" 50 leading to jurisdiction being declined. The Opinion restated a well-known fact that the ICJ had never declined jurisdiction on these grounds previously and acknowledged its special responsibility as the "principal judicial organ of the United Nations". ${ }^{1}$ One of the most important "compelling" reasons against the exercising of its jurisdiction was the proposition advanced in a number of submissions that "the request concerns a contentious matter between Israel and Palestine" 52 lacking Israeli consent. In response, the Court turned to its jurisprudence to reaffirm that advisory opinions as opposed to contentious cases do not ipso facto require a state's consent and that previous opinions had been rendered in the absence of

41 ICJ Reports 2004, 136, paras. 38-41.

42 ICJ Reports 2004, 136, para. 37.

43 ICJ Reports 2004, 136, at 204 (sep. op. Koroma), para. 3.

44 ICJ Reports 2004, 136, para. 38.

45 ICJ Reports 2004, 136, para. 41.

46 Legality of the Threat or Use of Nuclear Weapons, Advisory Opinion, ICJ Reports 1996, 26.

47 ICJ Reports 2004, 136, para. 41.

48 ICJ Reports 2004, 136, para. 42.

49 ICJ Reports 2004, 136, para. 43.

50 Certain Expenses of the United Nations, Advisory Opinion, ICJ Reports 1962, 155.

51 Citing United Nations Charter, art. 92, ICJ Reports 2004, 136, para. 44.

52 ICJ Reports 2004, 136, para. 46. 
consent. ${ }^{53}$ So as to distinguish the Permanent Court of International Justice (PCIJ) case of Eastern Carelia, ${ }^{54}$ the Court relied on Western Sahara's dictum that jurisdiction could be upheld despite the lack of consent as well as the presence of a bilateral dispute as long as hearing the matter was not "incompatible with the Court's judicial character". 55 The Court acknowledged that Israel and Palestine had "expressed radically different views". ${ }^{6}$ It also recognized an aspect of the case partly comprised a bilateral dispute, however, as in the Western Sahara case, it chose to focus on the relationship between its advisory jurisdiction and the mandate of the General Assembly. It held the construction of the wall "to be directly of concern to the United Nations". ${ }^{57}$ The Opinion would primarily function as judicial assistance to the Charter-determined duties of the General Assembly, rather than act as a forum for a bilateral dispute. By using these arguments, the Court could carve out a legal niche for itself distinct from the broader, "political" conflict.

19. The Court considered and refuted four more challenges to its competence: that the Opinion would impede negotiations between the participants via the Roadmap; that the Court lacked adequate factual materials on the case, especially because of the absence of Israeli consent; that the Opinion would serve no useful purpose; and that Palestine did not come to the proceedings in good faith. ${ }^{58}$ First, with very little investigation of the ensuing negotiations, the Court erred on the side of jurisdiction when it argued that opinions differed as to the possible relationship between an Opinion and negotiations. Ultimately, it did not regard potential interference "as a compelling reason to decline" jurisdiction. ${ }^{59} \mathrm{On}$ the requirement of sufficient information, the Court again distinguished Eastern Carelia to hold instead that the current case did not require factual material only available from a non-consenting party. ${ }^{60}$ Instead, "the Court has at its disposal the report of the SecretaryGeneral, as well as a voluminous dossier submitted by him to the Court", the submissions from the pleadings and lastly, material available in the "public domain". ${ }^{61}$ Thirdly, in relation to the contention that the Opinion would be of no value, the Court held that it "cannot substitute its assessment of the usefulness of the opinion requested for that of the organ that seeks such opinion". ${ }^{62}$ Both the UNGA and UNSC would be free to "draw [their own] conclusions". ${ }^{63}$ Finally, the Court dismissed Israel's contention that Palestine's

53 ICJ Reports 2004, 136, para. 47.

54 Status of Eastern Carelia, Advisory Opinion, 1923, PCIJ, Series B, No. 5.

55 Western Sahara, Advisory Opinion, ICJ Reports 1975, paras. 32-33, in ICJ Reports 2004, 136, para. 47.

56 ICJ Reports 2004, 136, para. 48.

57 ICJ Reports 2004, 136, para. 49.

58 ICJ Reports 2004, 136, paras. 46-65.

59 ICJ Reports 2004, 136, para. 53

60 ICJ Reports 2004, 136, paras. 55-58.

61 ICJ Reports 2004, 136, para. 57. Cf. Judge Buergenthal's disagreement on this point, ICJ Reports 2004, 245 (sep. op Buergenthal), at para. 10.

62 ICJ Reports 2004, 136, para. 62.

63 Ibid. 
responsibility for acts of violence meant that it came to the case in bad faith and without "clean hands". ${ }^{64}$ This was not a "pertinent" consideration because the case involved a request by the UNGA, rather than a bilateral dispute per se. ${ }^{65}$

20. Judges Higgins and Kooijmans criticized aspects of the Court's reasoning in relation to its competence. Their reservations centred on the bilateral and political aspects of the case as well as the Opinion's ill-founded reliance on the Namibia decision. ${ }^{66}$ Both separate opinions indicate that the Court negotiated an uneasy compromise at times. Nevertheless, there was sufficient agreement for 14 of its 15 members to accept the UNGA's request and hear the matter on its merits.

\section{III.C. Merits}

21. The Opinion's discussion of the legal principles lacked detail. The Court's decision has especially been questioned in relation to its light treatment of international humanitarian law, human rights law, as well as the requirements of self-defense. ${ }^{67}$ These factors fall outside of this article's focus, but it is useful to note that the Court adopted its usual approach in obfuscating norm conflict and relying on the formalism. ${ }^{68}$ It must also be remembered that a number of participating States did not address issues of substance, because they had requested that the Court decline its jurisdiction. Thus, the available material from both the Court as well as various participants was somewhat superficial.

22. Before the Court could consider the legal consequences of the wall's construction, it needed to determine what bodies of law applied and whether any breaches of these laws had occurred within the Occupied Palestinian Territories. At the outset, it distinguished between those parts of the wall west of the Green Line (in Israel proper) and those in the Occupied Palestinian Territories. It held that only the latter were of relevance because any State was free to construct walls within its territory. ${ }^{69}$ Before it considered the applicable laws, it discussed

64 ICJ Reports 2004, 136, para. 63.

65 ICJ Reports 2004, 136, at para. 64.

66 Legal Consequences for States of the Continued Presence of South Africa in Namibia (South West Africa) notwithstanding Security Council Resolution 276 (1970), Advisory Opinion, ICJ Reports 1971, 12. ICJ Reports 2004, 207 (sep. op. Higgins), paras. 1-11; ibid., 219 (sep. op. Kooijmans), paras. 23-25.

67 For some responses to the Court's treatment of international humanitarian law, human rights and self-defense issues, see Ardi Imseis, Critical Reflections on the International Humanitarian Law Aspects of the ICJ Wall Advisory Opinion, 99 AJIL (2005), 102; Frédéric Mégrét, A Sacred Trust of Civilization, 1 JIL Int. Relat. (2005), 305; Sean D. Murphy, Self-Defense and the Israeli Wall Advisory Opinion: An Ipse Dixit from the ICJ? 99 AJIL (2005), 62; Adam M. Smith, Good Fences Make Good Neighbors?: The "Wall Decision" and the Troubling Rise of the ICJ as a Human Rights Court, 18 Harvard HR J (2005), 251; Christian J. Tams, Light Treatment of a Complex Problem: The Law of Self-Defence in the Wall Case, 16 EJIL (2005), 963; Ruth Wedgwood, The ICJ Advisory Opinion on the Israeli Security Fence and the Limits of Self-Defence, 99 AJIL (2005), 52.

68 ICJ Reports 2004, 207(sep. op. Higgins), para. 26. Further, Judge Higgins characterized the majority's strict definition of self-defense only applying between States as "formalism of an unevenhanded sort". Ibid., para. 34. For a useful discussion about the ICJ's penchant for denying norm conflicts, see Martti Koskenniemi, From Apology to Utopia: The Structure of International Legal Argument (Cambridge: Cambridge University Press, 2nd edn., 2005) 82-302.

69 ICJ Reports 2004, 136, para. 67. 
the territorial status of the Occupied Palestinian Territories since the time of the Mandate. Although the Opinion did not consider the territorial status of Palestine between 1948 and $1967,{ }^{70}$ it highlighted League of Nations principles pertaining to the territory: non-annexation and "the well-being and development of peoples". ${ }^{11}$ What was clear for the Court at least was the status of Palestine after the June War in 1967: it was under Israeli belligerent occupation. This recognition of Palestine's occupied status was reinforced by numerous UNSC resolutions issued since $1967 .^{72}$

23. Echoing the Mandate ideals, the Court first identified both the right of self-determination and the prohibition against the use of force as constituting the general legal principles applicable. It cited the East Timor case ${ }^{73}$ in support of the notion that "the right of selfdetermination of peoples today is a right erga omnes". ${ }^{74}$ This right therefore applied to Israeli policies, which included: building the wall, transferring its population to settlements in the Occupied Palestinian Territories and the resulting flight of Palestinians from the territory. These acts impeded the Palestinian right to self-determination and are discussed further below in this article's comparison of the pleadings and the Opinion. Although supportive of the notion of self-determination generally in the Occupied Palestinian Territories, Judges Higgins and Kooijmans argued that there was no direct relationship between the wall and this right; it could only be appreciated with regard to the broader context and this was beyond the mandate of the Court. ${ }^{75}$ Judge Higgins pointed out that the wall did not change the territorial status of Palestine: both before and after its construction Palestine would remain an occupied territory. This view placed too little weight on what the Opinion described as the expansionist aims embodied by the wall and that its construction amounted to de facto annexation. ${ }^{76}$ In such a case, the right of self-determination was being breached. Most of the Court was unwilling to accept Israeli statements about the "temporary" 77 nature of the structure, and thus interpreted the right of self-determination in a more contextual and flexible manner than Judges Kooijmans and Higgins.

70 Judge Al-Khasawneh applauded this approach of the Opinion's and explained the underlying motives of the Court: "The Court followed a wise course in steering away from embarking on an enquiry into the precise prior status of those territories not only because such an enquiry is unnecessary for the purpose of establishing their present status as occupied territories affirming the de jure applicability of the Fourth Geneva Convention to them, but also because the prior status of the territories would make no difference whatsoever to their status as occupied territories except that they were terra nullius when they were occupied by Israel, which no one would seriously argue given that discredited concept is of no contemporary application, besides being incompatible with the territories' status as a former mandatory territory." ICJ Reports 2004, 235 (sep. op. Al-Khasawneh), para. 8.

71 Citing ICJ Reports 1950, 131, in ICJ Reports 2004, 136, para. 70.

72 Particularly, UNSC Resolution 242 (1967), 22 November.

73 East Timor (Australia v. Portugal), Merits, ICJ Reports 1995, 102.

74 ICJ Reports 2004, 136, para. 88

75 ICJ Reports 2004, 207 (sep. op. Higgins), para. 30. ICJ Reports 2004, 219 (sep. op. Kooijmans), para. 32.

76 Cf. Kretzmer's critique on the Court's unsatisfying treatment of future acts: David Kretzmer, The Advisory Opinion: the Light Treatment of International Humanitarian Law, 99 AJIL (2005), 88, at 92.

77 According to Israel, the Wall's construction is "a non-violent and temporary measure of last resort". Written Statement of Israel, 30 January 2004, 7, para. 1.16 (www.icj-cij.org/docket/files/131/1579.pdf). 
24. After examining the various laws applicable and instances of Israeli breaches, the Court discussed the legal consequences for both Israel and other States. As the Court had determined that the wall's construction was in breach of the right to self-determination, international humanitarian law and human rights law, it held that Israel must respect its obligations under international law. Israel was required to stop and reverse the wall's construction. Relying on the Factory at Chorzów Case, ${ }^{78}$ the Court further held that Israel was required to make reparations, or where this was not possible, compensate the victims for the damage suffered during the wall's construction. ${ }^{79}$ As for other States, the Opinion stated that selfdetermination as well as aspects of international humanitarian law were "of an erga omnes character" ${ }^{\prime 80}$ permitting no derogation. ${ }^{81}$ Thus, in its dispositif the Court held:

(3) A. By fourteen votes to one, ${ }^{82}$

The construction of the wall being built by Israel, the occupying Power, in the Occupied Palestinian Territory, including in and around East Jerusalem, and its associated regime, are contrary to international law;

B. By fourteen votes to one,

Israel is under an obligation to terminate its breaches of international law; it is under an obligation to cease forthwith the works of construction of the wall being built in the Occupied Palestinian Territory ... to dismantle forthwith the structure therein situated, and to repeal or render ineffective forthwith all legislative and regulatory acts relating thereto...

C. By fourteen votes to one, Israel is under an obligation to make reparation for all damage caused by the construction of the wall in the Occupied Palestinian Territory...

D. By thirteen votes to two, ${ }^{83}$ All States are under an obligation not to recognize the illegal situation resulting from the construction of the wall and not to render aid or assistance in maintaining the situation created by such a construction...

E. By fourteen votes to one, ${ }^{84}$ The United Nations ... should consider what further action is required to bring to an end the illegal situation... ${ }^{85}$

25. Judge Buergenthal did not support the Court's jurisdiction and so he voted consistently against all dispositive paragraphs. Although Judge Higgins voted for paragraph 3 (D), she

78 Factory at Chorzów, Merits, Judgment No. 13, 1928, PCIJ, Series A, No. 17.

79 ICJ Reports 2004, 136, para. 153.

80 ICJ Reports 2004, 136, para. 157.

81 ICJ Reports 2004, 136, para. 159.

82 Judge Buergenthal to paragraphs 3 A, B and C.

83 Judges Buergenthal and Kooijmans in dissent.

84 Judge Buergenthal in dissent.

85 ICJ Reports 2004, 136, para. 163. 
expressed reservations about its operation, because it called for states "to ensure compliance by Israel with international humanitarian law". ${ }^{86}$ Judge Kooijmans argued that there was no positive duty for States in the Fourth Geneva Convention regarding breaches, and that it was not practicable for the Court to rule on this anyway. ${ }^{87}$ It was also unclear from the Court's discussion whether it was eliding the term erga omnes with jus cogens, especially in relation to the right of self-determination. ${ }^{88}$

26. Despite the Opinion's rather sketchy and shallow treatment of many aspects of the case, it still provides a useful statement on many international legal principles and needs to be appreciated for what it is: a difficult compromise reached by the overwhelming majority of members of the Court. For Falk "the degree of consensus is rather remarkable, given the controversial subject matter, and the far-reaching and drastic responses given to the General Assembly's question". ${ }^{89}$ Damrosch and Oxman were less forthcoming with praise for the Opinion, because substantial agreement between the judges "came at the price of a lowest-common-denominator approach to the reasoning of the opinion". 90 O'Keefe echoes these sentiments, arguing that the Opinion "is often unsatisfying in methodological and stylistic terms... [and it] is too prone to bald, ex cathedra pronouncements of law and fact, which give little indication of the Court's reasoning". ${ }^{91}$ At times the Opinion's "certain delphic quality" 92 may have been necessary because of the tense legal and political issues the case straddled, but O'Keefe still argues that the Court need not have been so "exceedingly spare" in its approach. ${ }^{93}$ An opportunity to clarify some particularly pertinent issues such as the emerging norm relating to self-defense, and the finer points of international humanitarian law was wasted. In her Separate Opinion, Higgins opines that she felt compelled to add to the Opinion not because of any major discrepancies with what was written. Rather, her "regrets are ... about what it has chosen not to write". ${ }^{4}$

27. The Court's Opinion can still serve our purposes here as a useful document with which to compare and assess the various governmental and inter-governmental positions advanced by the participants. As shown by Higgins, the bench's silences tell us a great deal about international law and its relevance to the broader Arab-Israeli case. In the

86 ICJ Reports 2004, 207 (sep. op. Higgins), paras. 37-39.

87 ICJ Reports 2004, 219 (sep. op. Kooijmans), paras. 46-50.

88 See, generally, Alexander Orakhelashvili, International Public Order and the International Court's Advisory Opinion on Legal Consequences of the Construction of a Wall in the Occupied Palestinian Territory, 43 Archiv des Völkerrechts (2005), 240.

89 Richard A. Falk, Towards Authoritativeness: The ICJ Ruling on Israel's Security Wall, 99 AJIL (2005), 42, 43.

90 Lori Fisler Damrosch and Bernard H. Oxman, Agora: ICJ Advisory Opinion on Construction of a Wall in the Occupied Palestinian Territory: Editors' Introduction, 99 AJIL (2005), 1, 1.

91 Roger O'Keefe, Legal Consequences of the Construction of a Wall in the Occupied Palestinian Territory: A Commentary, 37 Revue Belge De Droit Int (2004), 92, 126; Scobbie concurs with this position: Iain Scobbie (2004), Smoke, Mirrors and Killer Whales: the International Court's Opinion and the Israeli Barrier Wall, 5 German LJ, $1107,1107$.

92 O’Keefe, ibid., 126.

93 Ibid., 127.

94 ICJ Reports 2004, 207 (sep. op. Higgins), para. 20. 
following sections, I compare positions taken in the pleadings with both the statements and silences of the Court.

\section{Contesting the Court's jurisdiction}

28. In contrast with contentious ICJ cases, advisory opinions offer much greater scope for the participation of a range of States as well as inter-governmental organizations, and in the case of Palestine, nascent State entities. ${ }^{95}$ States are under no compulsion to submit written or oral arguments and non-State entities must first secure the permission of the Court. ${ }^{96}$ The prestige, prominence and authority of the Court and a given case may induce States to act, but there are also other considerations such as resources and priorities. In the Wall pleadings, many States participated, but many also chose to play no part. Links can be made between the relative regard for the proceedings among the States participating and their method of engagement. There was a much greater number of written as opposed to oral submissions and often those States requesting the Court to decline its jurisdiction—namely, various EU states, the US, Israel and some others—only submitted written arguments. There was an overwhelming consensus among these states on the issue of jurisdiction: negotiations through the prism of the Roadmap were to take priority over legal proceedings likely to jeopardize this process. Such a stance suggests that these mostly First World States regarded the role of the ICJ as of limited value in such a highly political matter. It would also seem that States were strongly influenced by regional and strategic affiliations. ${ }^{97}$ The views put forth in the majority of First World written submissions indicate a tendency to set clear boundaries between legal and political spheres in international life with law being deemed only appropriate for limited situations. It should also be noted that all State parties to the Roadmap's Quartet, namely Russia, the US, and the EU, submitted that the Court should decline its jurisdiction.

95 Despite significant scholarly attention generated by the Wall Opinion, very little work has considered the pleadings. Where scholars have considered the pleadings, they have tended to focus in particular on Israel's written submission, without considering a representative cross-section of participants, thus contributing to the notion of the Opinion as being a contentious case. Some authors who have considered other submissions include: Iain Scobbie, Words my Mother Never Taught me - "In Defense of the International Court", 99 AJIL (2005), 76; and Geoffrey R. Watson, The "Wall" Decision in Legal and Political Context, 99 AJIL (2005), 6.

96 Statute of the International Court of Justice, art. 66. In the Wall Opinion, the Court decided to invite submissions both from Palestine and the Organisation of Islamic Conference (OIC) and the Arab League. In the case of Palestine, it grounded its reasons on A/RES/ES-10/14 (discussed above), the Secretary-General's report as well as Palestine's "special status of observer [in the UN] and that ... [Palestine] is co-sponsor of the draft resolution requesting the advisory opinion". As for the Arab League and the OIC, "these two international organizations were likely to be able to furnish information on the question". President Shi, Opening Address, Public Sitting, CR 2004/1, 23 February 2004.

97 According to Hirsch, regional interests may well be of greater importance for Israeli compliance than any commitment to the international community as represented in the ICJ as well as the UNGA's request: "This social influence of international reference groups indicates that the position of states belonging to the Western group regarding the recent Advisory Opinion is of significance to Israeli decision makers, even if it is not translated into coherent sanctions". Moshe Hirsch, The Impact of the Advisory Opinion on Israel's Future Policy: International Relations Perspective, 1 JIL Int. Relat. (2005), 319, at 340. 
29. While strong agreement existed among mostly First World States in relation to the ICJ's minor role, ${ }^{98}$ there was a similar pattern for Third World, and particularly Arab, States regarding the importance and place of international law and the ICJ in resolving the protracted conflict. Many Third World States regarded the case to be of great importance. ${ }^{99}$ There were a disproportionate number of Third World States submitting oral (as well as written) statements and a connection can be made between the relative importance that these States placed on the proceedings and their participation. Saudi Arabia declared in the hearings that " $[\mathrm{t}]$ his is the first time ... Saudi Arabia has made an oral presentation to the International Court of Justice." 100 Other Third World States expressed their awareness of the "momentousness of the occasion" ${ }^{101}$ by declaring their reverence for the Court in more florid terms than their First World counterparts. ${ }^{102}$ This was especially so for small States, such as Belize and Cuba, which were cognizant of their minor international influence, but still wanted to make a contribution to the proceedings.

30. As in the case of Quartet States and Israel, there were identifiable allegiances and alliances within the pleadings as well as a degree of cross-referencing across submissions. ${ }^{103}$ The NAM States ${ }^{104}$ along with the Arab Group at the UN (which happens to comprise NAM members) were the co-sponsors of the original UNGA resolution requesting the Opinion and many submissions acknowledged these links. The Organisation of Islamic Conference (OIC) also submitted both written and oral pleadings and many of its members are both members of the $\mathrm{NAM}^{105}$ and the Arab League. ${ }^{106}$ Thus, it is not surprising that the OIC was invited to participate in the hearings. Palestine is a member, but also more importantly, Article 2 of the OIC Charter lists one of the Organisation's principle objectives as being: "to coordinate efforts for the safeguarding of the Holy Places and support of the struggle

98 Exceptions included Palau, Micronesia and the Marshall Islands, which followed the US by asking the Court to decline its jurisdiction. This was also the case for Cameroon, despite its membership in the OIC. Finally, although there was a relatively united European stance, some States broke away from this or were more sympathetic to the legal process as discussed below.

99 For Written Submission of Yemen, see www.icj-cij.org/docket/files/131/1581.pdf; and Professor Jean-Marc Sorel, Oral Statement of Belize, 24 February 2004, CR 2004/3, 14.

100 Ambassador Fawzi A. Shubokshi, Oral Statement of the Kingdom of Saudi Arabia, 23 February 2004, CR 2004/2, 43, para. 1 .

101 Professor Jean-Marc Sorel, Oral Pleadings of Belize, CR 2004/3, at p. 14, para. 1.

102 See especially Oral Statement of Malaysia, 24 February 2004, CR 2004/4; Oral Statement of Madagascar, 24 February 2004, CR 2004/4; and Oral Statement of South Africa, 23 February 2004, CR 2004/2. These states all spoke in the Emergency Special Sessions as well.

103 Sudan provides an example of cross-referencing amongst Arab states: "At the outset, we would like to associate ourselves with the Written Statements submitted to this Court by both the League of Arab States and the Organization [sic] of Islamic Conference (OIC), and we fully endorse their legal arguments, opinions and conclusions on the matter. We also subscribe to the views and legal arguments presented by Palestine and by other delegations appearing before this Court." Ambassador Abuelgasim A. Idris, Oral Statement of Sudan, 25 February 2004, CR 2004/5, 14, para. 2.

104 For a full list of NAM members, see www.nam.gov.za/background/members.htm

105 For example, in its written submission, Bangladesh highlighted its membership of both the NAM and OIC and linked this with its position in the pleadings. Oral Statement of Bangladesh, 23 February 2004, CR 2004/2, 59.

106 In addition, both the Arab League and the OIC are Observer Organisations within the NAM. 
of the people of Palestine, to help them regain their rights and liberate their land". ${ }^{107}$ The OIC has a committee overseeing the implementation of this Article "on the Arab-Israeli conflict in view of the fundamental connection between the Al-Quds ${ }^{108}$ [Jerusalem] question and the conflict". ${ }^{109}$ At the time of the pleadings, Morocco's King Mohammed VI was the chair of the Al-Quds committee, and consequently, Morocco listed this as a motivating factor in its participation. ${ }^{110}$

31. Similarly, the Arab League emphasized its own motivations in the pleadings as being directly "at the top of the League of Arab States' agenda since its creation in 1945. ${ }^{111}$ The League's Pact asserted the right of Palestine to independence. Accordingly, Palestine was granted the full membership in the Arab League". ${ }^{112}$ The matter of Palestine led to Egypt's decade-long suspension as well as the temporary transferral of the League's headquarters in Cairo after Egypt's peace treaty with Israel in 1979. Ultimately, the NAM, the Arab League and the OIC need not have given international law, and its embodiment in the form of the ICJ, such attention. Many member States of these organizations have been actively involved in diplomatic efforts regarding both the conflict and the wall in particular. However, their choice in supporting the legal process suggests a commitment to legal institutions as well as a faith in international legal principles. Links between the language of faith and international law for Third World States will be explored further below.

32. A few observations about the relative quality of the legal teams and statements presented are noteworthy. Written submissions varied dramatically in terms of their quality of style and length as well as considered treatment of legal arguments. In instances where States placed great weight on the jurisdiction and substantive findings of the Court, submissions were often detailed and well polished, as in the case of Saudi Arabia, the Arab League, the OIC, Malaysia, South Africa and, particularly, Jordan and Palestine. ${ }^{113}$ In

107 The Charter can be found on the OIC's website (www.oic-oci.org/).

$108 \mathrm{Al}$-Quds is the Arabic name for Jerusalem, which is the third most holy site for Muslims. This is reflected in the derivation of the name: the word is based on the verb qadasa, ق ق قـ (to be holy) and the literal meaning of quds is holiness, sacredness, sanctity: J M Cowan (ed), The Hans Wehr Dictionary of Modern Written Arabic, (Ithaca: Spoken Languages Services, 4th edn., 1994). The use of Al-Quds instead of Jerusalem is a highly symbolic act on the part of Arabs who have come to see "Jerusalem" as signifying a unified Jewish capital, see Y Suleiman, A War of Words: Language and Conflict in the Middle East (Cambridge: Cambridge University Press, 2004), at 175. When I was in Al-Quds/Jerusalem in June 2005, I noticed that the (Israeli-made) Arabic street signs referring to the city used a transliteration of Jerusalem, rather than Al-Quds.

109 This statement can also be found on the OIC's website, above n. 107.

110 Written Submission of the Kingdom of Morocco, 1 (www.icj-cij.org/docket/files/131/1585.pdf).

111 For a full list of member states, see the Arab League's website (www.arableagueonline.org/las/index_en.jsp).

112 Written Submission of the League of Arab States, 28 January 2004, para 2.1 (www.icj-cij.org/docket/files/ $131 / 1545 . p d f)$.

113 Written Submission of Saudi Arabia (www.icj-cij.org/docket/files/131/1543.pdf); Written Submission of the League of Arab States, ibid; Written Submission of the Organisation of Islamic States (www.icj-cij.org/docket/ files/131/1589.pdf); Written Submission of Malaysia (www.icj-cij.org/docket/files/131/1625.pdf); Written Submission of South Africa (www.icj-cij.org/docket/files/131/1597.pdf); Written Submission of Jordan (www.icj-cij.org/docket/files/131/1559.pdf); and Written Submission of Palestine (www.icj-cij.org/docket/ files/131/1555.pdf). 
contrast, many States not supportive of the Court's jurisdiction submitted shorter and often perfunctory documents. Israel, however, had a strong interest in blocking the pleadings, and so its written submission was quite detailed in relation not only to jurisdiction, but also inadvertently, substance. From a perusal of both the drafting style and the legal teams employed, it is clear that there were disparities in the time and resources outlaid in the proceedings. ${ }^{114}$ Palestine's legal team, in particular, comprised a host of eminent international law experts, who were given the liberty to work on the case as they saw fit; they were not under any instructions from Ramallah. ${ }^{115}$ This fact alone is significant; ${ }^{116}$ it suggests that Palestine's faith in the processes of international law-as embodied in the disciplines' finest-meant that no political direction was needed. Instead, international legal principles could speak for themselves.

\section{Strategies of argument}

33. This section is concerned with two central strategic devices employed by the participants in submitting their case: the use of language and the use of history. Both of these strategies reveal underlying Third World normative evaluations about international law.

\section{V.A. Speaking before the Court}

34. States participating in the pleadings did not necessarily share the same vocabulary or understanding of international law. It is also evident from a comparison of the language used in the lead up to the Opinion in the Emergency Special Sessions, that participants were aware of the unique discourse that the Advisory Opinion elicited-language of the pleadings was far less emotive and florid.

35. Choice of language was of importance for both the participants and the Court in relation to the name of the case and its focus: the wall. Although, the Court must have been aware of the controversy over terminology, it chose not to delve into this. ${ }^{117}$ In

114 Syria's submission, for example, contained numerous errors and was utterly incoherent at times. A sample of its style illustrates this: "The second: is what the second article referred to when expecting three cases in which the state could not have the state of emergency as a pretext. The first of these cases refers that it is not allowed to have the state of emergency as a pretext to violate a clear rule of the international law. These rules are not to be disobeyed for any reason. Consequently, we say here that catching the others' territories by force, settling, imposing the public punishment policy and adopting racial separation policy are on top of clear international rules that could not be violated or disobeyed with the pretext of existence." Written Submission of the Syrian Arab Republic, 30 January 2004, 24 (emphasis in original) (www.icj-cij.org/docket/files/131/1567.pdf).

115 For an insider's account of his experiences on Palestine's legal team, see Pieter H. F. Bekker (2005), The World Court's Ruling Regarding Israel's West bank Barrier and the Primacy of International Law: An Insider's Perspective, 38 Cornell ILJ, 553, 557.

116 In particular, it should be noted that a member of the Palestinian team, James Crawford has written on the territorial status of Palestine before, essentially holding that it does not yet manifest the qualities of statehood, above n. 5; James Crawford, The Creation of the State of Palestine: Too Much Too Soon?, 1 EJIL (1990), 307; and James Crawford, The Creation of States in International Law (Cambridge: Cambridge University Press, 2nd edn., 2006), 421-448.

117 Scobbie also acknowledged this controversy in his discussion of the Opinion. Scobbie (2005), above n. 95, 76, footnote 1. 
explaining its use of the word "wall" (as opposed to "fence" or "barrier"), the Court simply stated that other words "are no more accurate if understood in the physical sense". ${ }^{118}$ However, the Court did qualify its use of the word later in the Opinion by describing the surrounding circumstances as creating a "regime": ${ }^{119}$ the wall was more than a simple edifice; it took on complex qualities with legal consequences. This idea can be attributed to a number of submissions from Arab States, including Palestine and Jordan. ${ }^{120}$

36. Within the pleadings themselves, there is an unambiguous correlation between Third World support for the Court's jurisdiction and their use of the term, "wall". Every Arab State and most Third World States (except those not in favour of the request: the Pacific States and Cameroon) subscribed to this pattern. Jordan's Prince Al-Hussein voiced the Third World position when he argued before the Court that the case "concerns a wall. And not just 'a' wall, but a very specific wall...[that] is not just a simple fence". ${ }^{121}$ For those Western States asking the Court to decline jurisdiction, many chose to use the term, "barrier" instead, which conjures up the image of a structure less total than a wall. The use of the term "fence" was associated with Israel's position and is "highly symbolic", suggesting, as it does, an insubstantial and semi-permanent structure. ${ }^{122}$ Israel consistently used (and continues to use) the term and only a few States followed suit in their submissions, all of which favoured negotiations over the Opinion. ${ }^{123}$ Israel went into detail about this:

The use of the term "wall" in the resolution requesting an opinion is neither happenstance nor oversight. It reflects a calculated media campaign to raise pejorative connotations in the mind of the Court of great concrete constructions ${ }^{124}$ of separation as the Berlin Wall, intended to stop people escaping from tyranny. ${ }^{125}$

118 ICJ Reports 2004, 136, para. 67.

119 For example, ICJ Reports 2004, 136, para. 134.

120 "The wall, far from being a simple self-standing security measure, is thus to be understood as a regime serving Israeli policy towards the annexation of the West Bank or substantial parts thereof" (emphasis added), Written Submission of Jordan, 97, para. 5.151, above n. 113; "The Wall is not a physical structure. It is a whole regime." Mr M. Nasser Al-Kidwa, Oral Statement of Palestine, 18, para. 4, CR 2004/1; Written Submission of Palestine, para. 11, above n. 113 .

121 Written Submission of the Hashemite Kingdom of Jordan, above n. 113, 53.

122 In the words of Professor Sorel, Belize's counsel, "Like the General Assembly, I shall use the word 'Wall', not forgetting that other, highly symbolic expressions are used by Israel to describe this construction referred to as 'security fence' then 'security barrier'". Professor Jean-Marc Sorel, Oral Statement of Belize, CR 2004/3, 15, footnote 3 .

123 Written Submission of Belgium (www.icj-cij.org/docket/files/131/1635.pdf); Written Submission of the European Union (www.icj-cij.org/docket/files/131/1615.pdf).

124 This statement is directly contradicted by the Arab League, which argued that Israel is denying the effects of the wall "by calling the 'fence' a temporary security measure. But this claim veils the true situation. It is public notice that major parts of the Wall are built in a very solid way, concrete structures, ditches, and so on". Professor Michael Bothe, Oral Statement of the League of Arab States, CR 2004/5, 29. This position is corroborated by footage on B'Tselem's (a prominent Israeli human rights organization) website www.btselem.org/ English $/$ Photo_Archive/List.asp?x_Concatenate $=158 z$ _Concatenate $=$ LIKE, 27\% 25\%,25\%27\%.

125 Written Submission of Israel (www.icj-cij.org/docket/files/131/1579.pdf), 10, para 2.7. 
37. This notion of the Berlin Wall was explored by the Arab League in its oral statement, and was the only delegation to do so. ${ }^{126}$ The broader idea of separation, however, was expressed by some other Arab States, which referred to the "apartheid wall"127 and the "segregation wall". ${ }^{128}$

38. Language choice over "wall" was bolder in the political setting of the earlier Emergency Special Settings discussed above. During the Emergency Special Sessions, speakers were more forthright in their language. Prominent participants in the case also spoke at the Sessions and followed the Palestinian delegate's condemnatory language regarding the wall, using phrases such as "expansionist annexation wall" (Palestine), ${ }^{129}$ "expansionist conquest wall" (Palestine), ${ }^{130}$ the "Israeli expansionist wall" (Malaysia speaking for NAM) ${ }^{131}$ and "that expansionist wall" (OIC). ${ }^{132}$ Israel also employed much more inflammatory language for the wall: "this is the Arafat fence. This is the fence that Arafat built". ${ }^{133}$ None of these expressions were employed before the Court; the participants were aware of the different language required of them and translated their perspectives accordingly.

39. In both the pleadings and the Opinion itself, ideas of "existence" were touched on through certain linguistic techniques. As in the case of the use of "wall", the Court refused to be drawn into these debates on Palestine's existence: "[a]s regards the principle of the right of peoples to self-determination, the Court observes that the existence of a 'Palestinian people' is no longer in issue". ${ }^{134}$ However, Palestine was described by Italy as existing "still in an inchoate state" 135 and Israel was able to demonstrate this idea by always using quotation marks when discussing Palestine; it would seem that Palestine was in a state of limbo. This was of such importance for Malaysia that it specifically addressed the issue during the pleadings: "Malaysia takes strong exception to the pejorative way in which Israel refers to Palestine throughout its Written Statement, such as the use of inverted commas to refer to Palestine". ${ }^{136}$ Syria also adopted the technique against Israel by employing quotation marks when referring to anything Israeli, including Prime Minister, Ariel Sharon. ${ }^{137}$

40. Israel's existence as a recognized State has been a contested issue for both Arab and Muslim States more generally. Many continue to refuse not only to make peace with

126 Professor Michael Bothe, Oral Statement of the League of Arab States, CR 2004/5, 21-22.

127 Written Submission of the League of Arab States, above n. 112, 7 para. 1.4.

128 Written Submission of Kuwait (www.icj-cij.org/docket/files/131/1561.pdf).

129 A/ES-10/PV.21, 3.

130 Ibid 9.

131 Ibid.

132 Ibid.

133 A/ES-10/PV.23, 6.

134 ICJ Reports 2004, 136, para. 118.

135 Written Submission of Italy (www.icj-cij.org/docket/files/131/1593.pdf), 4.

$136 \mathrm{Mr}$ Datuk Seri Syed Hamid Albar, Oral Statement of Malaysia, 24 February 2004, CR 2004/4, 24.

137 However, it should be noted that Syria's submission was so poorly drafted that quotation marks were occasionally forgotten, but the intention remains clear nevertheless. 
Israel or enter into diplomatic relations, but even to acknowledge its existence. ${ }^{138}$ This dissonance between legal fact and political predisposition was illustrated in parts of the written submission of the OIC, where the presence of Israel remained ambiguous; it was unclear whether the OIC was recognizing Israel or not. ${ }^{139}$ This example indicates that choices over language were of primary concern for certain States participating in the case. Some words and phrases stretched the accepted discourse(s) of neutral legal language and would appear to have strayed into the frontier beyond international law's linguistic capacities.

41. Many participants employed inflammatory language in the UNGA Sessions and this was carried over to a lesser extent in the advisory pleadings themselves. Koskenniemi has argued that international law cannot be used as a discourse to express the full range of human emotions because certain values cannot be translated to the idiom of legal reason. ${ }^{140}$ Did emotional discourses remain within the bounds of legal language and was this discourse understood in the courtroom? This is a question that cannot be answered with any precision, but it would seem from the Court's rejection of the more extreme phrases employed, that their use fell on deaf ears; their meaning was lost on the border between legal and non-legal language. Words and expressions such as apartheid, bantustantization, racial discrimination, ghettoization, Israel as colonizer and its behaviour towards Palestinians as rendering them in a category of "sub-humans", ${ }^{141}$ were used frequently in the pleadings. However, their use was exclusively by Third World States, particularly Arab States.

42. It is possible to argue that Third World States had a more expansive notion of the role that international law could play in highly contested matters. The action of these States echoes Kritsiotis's supposition about international law's expanding linguistic and participation base: these States were trying to refashion the rhetoric of international law, and thus, the spheres of its application. ${ }^{142}$ Here, Third World States had argued for the Court's jurisdiction along the familiar lines of the matter conforming to a "legal" issue. Once inside the Peace Palace, Third World States maintained an awareness of legal niceties

138 This is also reflected in one of most widespread English/Arabic dictionaries, Al-Mawrid, published in Beirut. Under "I", in the English section, it is only possible to find an entry for the adjective, "Israeli". A noun for the place does not exist in this dictionary.

139 Written Submission of the OIC, above n. 113, 6-7.

140 Martti Koskenniemi, Faith, Identity, and the Killing of the Innocent: International Lawyers and Nuclear Weapons, 10 Leiden JIL (1997), 137, 156. A particularly emotive outburst came from Cuba: "It is totally impossible to estimate the degree of mourning imposed on Palestinian families, of pain to the mothers of the Palestinian children who have died as a result of violence exerted by the occupying Power, and the systematic humiliation to which the Palestinian people are subjected". Written Statement of Cuba (www.icj-cij.org/ docket/files/131/1629.pdf), 1 .

141 Written Statement of the Organisation of Islamic Conference, above n. 113, 12, para. 42. This idea of "sub-human" conjures up imagery of the Holocaust and this device is quite deliberate on the OIC's part. In the preceding section, the submission makes a direct connection between the European Holocaust and the role of European guilt in the creation of Israel. The OIC is not so subtly reminding readers that Jews were rendered as sub-human in living memory and it is suggesting that the Jewish state is now behaving in a similar fashion towards Palestinians because of Israeli disregard for fundamental human rights principles. Also see the OIC Written Submission, above n. 113, 5, para. 20.

142 D. Kritsiotis, The Power of International Law as Language, 34 California Western LR (1997-1998), 397. 
in toning down some of their rhetoric. However, the debates over word use and occasional flights into inflammatory language challenged clear divisions between law and politics. Given the Court's response, however, it would also appear that this language remained on the margins of international law, or even outside it.

\section{V.B. The use of history}

43. Because historical narratives are mainly related to a case's substance, it is not surprising that those mainly First World States overlooked matters from the past. Choices about the relationship between international law as well as its ability to confront its own past informed States' support for, or opposition to, jurisdiction. Although former imperial powers, such as France and Britain, submitted substantial dossiers, neither revisited their own responsibility in the creation of the Mandate system. Either they were uncomfortable with their record or wanted it left unexamined, because they regarded the past as irrelevant to the wall's construction, which had begun only a few years before proceedings.

44. As a strategy of legal argument, the First World position can be contrasted with approaches taken by many Arab participants. Although Arab and non-Arab submissions within the Third World group were quite evenly balanced, only Arab participants (including the partly-Arab OIC) discussed the historical record in detail. This indicates greater Arab sensitivity to the colonial past even though many other Third World States had also experienced foreign rule. For a number of Arab States, participation in the Wall Case was an opportunity not only to revisit the past, but also to offer their own narrative about events that are seen to have direct influence today. Jordan's introductory comment highlights the central role of the historical record in legal proceedings:

In addressing the issues which arise in these proceedings, Jordan is constrained to note that the substance of the matter which is the subject of these advisory proceedings raises some very major issues of law and fact, particularly the historical facts going back more than 50 years. Those facts shape the legal issues which call for consideration in these advisory proceedings. Moreover, the legal issues themselves are exceedingly complex and in many respects controversial, and require the most careful analysis. ${ }^{143}$

45. Other Arab participants to echo these sentiments included Palestine, Egypt, Sudan, the Arab League and the OIC. There was also a degree of reliance between Arab States on each other's submissions, such as in the case of Egypt: "Since various memoranda submitted to the Court by Arab countries and the League of Arab Nations, have elaborately depicted the historical background of this issue, therefore, the Arab Republic of Egypt would like to refer thereto in order to avoid repetition". ${ }^{144}$ This statement suggests shared positions on both the importance of history as well as its content.

143 Written Statement of Jordan, above n. 113, 6, para. 1.6.

144 Written Statement of the Arab Republic of Egypt (www.icj-cij.org/docket/files/131/1547.pdf), 16. 
46. All Arab submissions considering the historical record as well as the Court's summary began their analysis at the time of the Mandate, thus indicating consensus about the historical trajectory relevant for the Advisory Opinion. Although both the Court's Opinion and Arab submissions highlighted the Mandate ideals of sacred trust and (eventual) independence, the Court's "neutral" account of the period obscured the colonialist agendas of the period, such as the role of European powers in the Mandatory system and its allocation of responsibility, as well as the impact of the Balfour Declaration on the Arab inhabitants of Palestine.

47. A thorough investigation of the historical record was not required of the Court; it was asked to consider the legal consequences arising from recent events. However, many Arab submissions devoted considerable attention to history, because in their opinion, it was inextricably linked to the case at hand. Similarly, Judge Elaraby from Egypt distinguished himself from others on the bench through his emphasis on the historical record:

An historical survey ... may appear as academic, without relevance to the present events. The present is however determined by the accumulation of past event and no reasonable and fair concern for the future can possibly disregard a firm grasp of past events. In particular, when on more than one occasion the rule of law was consistently side-stepped. ${ }^{145}$

48. In his discussion on the legal status of the Occupied Palestinian Territories, Judge Elaraby sought to show how the case for Palestine's non-annexation by Israel could be bolstered by the historical record; ${ }^{146}$ the past and the present were interdependent.

49. In their strategic use of history, Arab participants and the OIC not only demonstrated their greater reliance on history as a method of international legal argument, but they also explored some substantive and ongoing themes at work within international law. Neither international law itself nor colonial practice was regarded neutrally; each submission's narrative was flavoured by a normative evaluation of international society's characteristics in the past and in the present.

50. It is useful at this point to apply the lenses of recent scholarship from Third World Approaches to International Law or TWAIL. ${ }^{147}$ Particularly in its "TWAIL II" form,

145 ICJ Reports 2004, 246 (sep. op. Elaraby), para. 2.1.

146 Ibid., para. 2.5 .

147 For some representative contributions, see Antony Anghie, Imperialism, Sovereignty and the Making of International Law (Cambridge: Cambridge University Press, 2005); Nathaniel Berman, In the Wake of Empire,) 14 American University ILR (1999), 1515 (First Annual Grotius Lecture, American Society of International Law); James T. Gathii, Alternative and Critical: The Contribution of Research and Scholarship on Developing Countries to International Legal Theory, 41 Harvard ILJ (2000), 263; Frédéric Mégrét, From "Savages" to "Unlawful Combatants": A Postcolonial Look at International Humanitarian Law's "Other", in A Orford, International Law and Its Others (Cambridge: Cambridge University Press, 2006) 265-317 [Mégrét does not explicitly identify himself as a TWAILer, but his analysis draws heavily on other TWAIL research and is a refreshing take on international humanitarian law]; Vasuki Nesiah, Placing International Law: White Spaces on a Map, 16 Leiden JIL (2003), 1; B Balakrishnan Rajagopal, International Law from Below: Development, Social Movements and Third World Resistance (Cambridge: Cambridge University Press, 2003); and the special issue on Alvárez, 19 Leiden JIL (2006). 
scholars have been interested in tracing the ongoing relationship between colonialism and the law. Chimni has categorized TWAIL II as having a more critical and structural approach to international law than TWAIL I. ${ }^{148}$ TWAIL II authors are sceptical about international law's capacity to be truly inclusive of non-European, post-colonial peoples. International law is portrayed as structured by its colonial past, and despite Third World participation in the international system as sovereign, independent states, international law continues its colonialist, civilizing tendencies in new forms. TWAIL I approaches, on the other hand, are generally much more optimistic and are imbued with significant faith in the potentiality of international law as liberator.

51. Where the historical record is considered in Arab and OIC submissions, there is a strong resemblance to TWAIL I approaches: international law's relationship with past colonial practices is distinguished from its inclusive and anti-colonialist qualities in the post-1945 world. Many Arab and NAM States described Israel's actions in the Emergency Special Sessions and pleadings as "colonial", thus trying to demonstrate that colonialism persists in the post-colonial era. However, these accounts also tended to suggest that Israel's actions were exceptional as well as contrary to international law; as the Court itself pointed out, the prohibition against the acquisition of territory by force is now a fundamental legal doctrine. ${ }^{149}$ For many Third World States, there was a conviction that international law's past has qualitatively changed; norms against territorial annexation show that European colonialism is an event of the past even if it did result in lasting effects on the ground for Palestinian selfdetermination. Rather than mistrust international law's capacity for liberation into the future as many TWAIL II writers do, it seems that Arab historical accounts acknowledged the role of history not so much to remind us about European colonialism per se, but to make us aware of how similar Israeli practices are with events of the past. Thus, the recounting of historical events to highlight themes in legal doctrine was a strategic device for a number of Arab States as well as the OIC. We were made aware of Arab endorsement of international law's vital role—as well as its legitimacy—in international society today.

\section{V.I. The promise of doctrine?}

52. Having surveyed some strategic devises of argument, this final section turns to matters of substance. Third World and First World perspectives are contrasted and compared with the Court's doctrinal position on the issues of conquest, self-determination and human rights norms. The final part of this section comes full circle by looking again at the issue of the Court's jurisdiction to reflect on the role of the ICJ in resolving even the most "political" of disputes.

53. The first two interrelated legal principles applicable in the Wall Opinion related to the prohibition against the acquisition of territory through force and the right to selfdetermination. Here, the Court cited Article 2(4) of the UN Charter banning the use of

148 B. S. Chimni, Towards a Radical Third World Approach to International Law, 2 International Centre for Comparative Law and Politics Review (2002), 14.

149 ICJ Reports 2004, 136, para. 117. 
force ${ }^{150}$ It then linked this general prohibition to the action of territorial annexationconquest-by referring to the Declaration on Principles of International Law concerning Friendly Relations and Co-operation among States (resolution 2625 (XXV)) as well as ICJ jurisprudence to confirm that this rule was customary. ${ }^{151}$ The Opinion then discussed the right to self-determination by relying on UNGA Resolution 2625 (XXV), its jurisprudence "on a number of occasions" and common Article 1 in the two human rights covenants. ${ }^{152}$ Later, the Court went on to hold that the right to self-determination was ergaomnes, but it remained unclear whether the Court was actually referring to the notion of jus cogens as well. ${ }^{153}$ This area of law remains unclear and many pleadings reflected this confusion. ${ }^{154}$

54. Confusion about norm conflict was also evident in submissions from Third World States. Participants generally gave only scanty consideration to these principles on conquest and self-determination, but they were nevertheless referred to as constituting the core of international legal norms for a number of States. For example, Palestine regarded the norm against the acquisition of territory to be so well accepted, which it did not need to cite any authorities in its submission; international law was irrefutable here. ${ }^{155}$ Many States specifically relied on UNGA Resolution 2625 (XXV) and some sought to rely on the Kellog-Briand Pact of 1928. ${ }^{156}$ Most First World States did not consider the merits, but even where they did, there was more of a tendency to explore international humanitarian law and human rights issues. ${ }^{157}$ Norms about conquest and self-determination were of far greater concern to Third World States. For States only recently endowed with full international legal personality, they could appreciate the primacy of Statehood more than their First World counterparts.

55. Culturally, it is interesting to consider how Third World States approached the question of human rights and their application in the Occupied Palestinian Territories. In its Opinion, the Court discussed the scope for human rights derogation in some detail to hold that Israel was still bound by a number of human rights norms. ${ }^{158}$ No State argued that human rights law was not applicable in the Occupied Palestinian Territories, because, in the words of South Africa, such norms apply to the individual and not to the State. ${ }^{159}$

150 ICJ Reports 2004, 136, para. 87.

151 Ibid.

152 ICJ Reports 2004, 136, para. 88.

153 For a discussion about Judge Al-Khasawneh's implicit linking of the two concepts, see Iain Scobbie, Unchar$\mathrm{t}(\mathrm{er}) \mathrm{ed}$ Waters?: Consequences of the Advisory Opinion on the Legal Consequences of the Construction of a Wall in the Occupied Palestinian Territory for the Responsibility of the UN for Palestine, 16 EJIL (2005), $941,949$.

154 See, for example, Written Statement of Jordan, above n. 113, paras. 5.37, 5.100

155 Written Statement of Palestine, above n. 113, 156, para. 347.

156 Written Submissions of Cuba, above n. 140, Written Statement of Senegal (www.icj-cij.org/docket/files/131/ 1643.pdf); and Written Statement of Morocco, above n. 110. This agreement was not mentioned by the Court.

157 Written Statement of the UK (www.icj-cij.org/docket/files/131/1605.pdf), at p. 23-24; Written Statement of Ireland (www.icj-cij.org/docket/files/131/1613.pdf), at paras. 2.1-2.14.

158 ICJ Reports 2004, at paras. 136-137.

159 Written Submission of South Africa, above n. 113, at p. 22, para. 55. 
Commentary on human rights in general was scant, but the unquestioning way in which participants recognized provisions as applicable in all contexts is significant. For example, Lebanon stated that human rights treaties "now embody unquestionable universal values". ${ }^{160}$ The OIC echoed these sentiments "by strongly reaffirming the inalienable and universal nature of human rights regardless of the circumstances in which a particular group finds itself". ${ }^{161}$ Although Gross has argued that the elision of human rights and international humanitarian law protections can weaken the position of persons in occupied territories, ${ }^{162}$ Third World States overlooked these subtleties in support of "the more law, the better" approach.

56. Although debate persists within some quarters about the European biases inherent in human rights norms, ${ }^{163}$ Arab States did not subscribe to such views in their submissions. On the contrary, their positions demonstrate support for such norms as well as sometimes detailed analysis of how such norms apply on the ground. In its written statement, for example, Palestine considered the ramifications of the wall's construction on the various human rights of the Palestinian population. It traced the actions of individuals and communities in their daily lives and indicated that human rights guarantees are embedded in all levels of social and political life. In his statement for Palestine, Professor Vaughan Lowe argued that human rights in the case fell into two categories: those affected directly by the construction of the wall (such as property seizures) and rights violated as a consequence (such as restrictions on movement). ${ }^{164}$ This position indicates how human rights were presented as far more than rigid rules; context and law were interdependent. Thus, Third World States and their lawyers drew on norms on human rights, self-determination and the prohibition against conquest as a shield in their defence of Palestinian (and post-colonial) interests. The promise of doctrine was embraced, rather than rejected as in the case of most First World States.

57. Matters of jurisdiction and propriety reflect normative positions about the role of the ICJ as well as international law within international society. Overall, most consideration was given by both the Court and the various participants to the matter of jurisdiction. Submissions often relied on very similar material to reach opposite positions. This indicates that international law (especially the jurisprudence of the Court in relation to the exercise of its jurisdiction) was interpreted and applied by actors in different ways. All submissions were informed by a particular reading of the relationship between law and politics and more specifically, how the "peaceful settlement of this dispute"165 fitted into such a

160 Written Statement of Lebanon (www.icj-cij.org/docket/files/131/1563.pdf), at p. 8, para. 37.

161 Written Statement of the OIC, above n. 113, 12, para, 42.

162 Aeyal M. Gross, Human Proportions: Are Human Rights the Emperor's New Clothes of the International Law of Occupation?, 18 EJIL (2007), 1.

163 See, for example, Ann Elizabeth Mayer, Universal Versus Islamic Human Rights: A Clash of Cultures or a Clash within a Construct?, 15 Michigan JIL (1994), 307; and Abdullahi An-Na'im, Islam and Human Rights: Beyond the Universality Debate, in Proceedings of the 94th Annual Meeting of the American Society of International Law (2000), 95.

164 Professor Vaughan Lowe, Oral Statement of Palestine, CR 2004/1, 23 February 2004, paras. 15-26.

165 Professor Jean-Marc Sorel, Oral Statement of Belize, CR 2004/3, 14. 
relationship. In the pleadings, those participants favouring the Court's jurisdiction also tended to be more supportive of international law's primary role in resolving international disputes. ${ }^{166}$ Both positions also acknowledged current diplomatic efforts in relation to the Road Map. However, there were strong differences over the relationship between the advisory function of the Court and negotiations - that is law and politics. Submissions from both perspectives highlighted their support for negotiations and also often detailed their direct role in such efforts. ${ }^{167}$

58. Like many First World States, Arab States have participated in negotiations to solve the Arab-Israeli conflict, but they did not see negotiations as precluding international law's role. Instead, Arab submissions embraced negotiations within the wider context of international law, where the advisory opinion was one important legal device in advancing the aim of Israeli compliance with international law. Thus, international law and international politics were not regarded as opposites, but as mutually interdependent forces within international society.

59. Typically, First World States, on the other hand, sought to construct a clear line (or wall) between political, diplomatic processes and international law. The starkest example of this position was provided by the US, which rarely mentioned international law. Instead, detailed discussion about diplomatic efforts demonstrated how international law was irrelevant and unhelpful in relation to the wall's construction and the ArabIsraeli conflict in general. European positions were more nuanced in their approach to the advisory opinion. EU States voted en masse for Resolution ES 10/13 seeking Israel to stop its construction of the wall as it was in breach of international law. Even though these legal ramifications were clear, the process of seeking Israeli compliance was seen as a political one. ${ }^{168} \mathrm{~A}$ request for an Advisory Opinion was inappropriate, requiring as it would, the Court to step into political territory.

60. Some First World States were more supportive of the Court's wider role. For example, although it was part of the EU bloc, France's submission wavered in its support for an advisory opinion. It discussed substantive issues of international humanitarian law and human rights and deferred responsibility by arguing that questions of jurisdiction should be left to the Court. ${ }^{169}$ Other EU States, such as Ireland, Cyprus and Malta, were less forthright in their positions, but supported the case and the

166 As embodied in the Arab League's statement: "The current request means the General Assembly has recognised the importance of the role of law in the solution of the problem". Professor Michael Bothe, Oral Statement of the League of Arab States, CR 2004/5, 22.

167 For example, both Egypt and Saudi Arabia draw attention to their efforts in previous negotiations to demonstrate that their support for the Advisory Opinion is not about taking sides; they are supportive of both legal and political processes and think that they can rely on each other to an extent. Written Submission of Egypt, above n. 144, 3; and Ambassador Fawzi A. Shubokshi, Oral Statement of Saudi Arabia, CR 2004/2, 46, para. 16.

168 Written Submission of Germany (www.icj-cij.org/docket/files/131/1599.pdf), 3; Written Statement of the Netherlands (www.icj-cij.org/docket/files/131/1627.pdf); Written Statement of Spain (www.icj-cij.org/ docket/files/131/1633.pdf); and Written Statement of Italy, above n. 135.

169 Written Submission of France (www.icj-cij.org/docket/files/131/1591.pdf), 17, para. 74. 
Court. ${ }^{170}$ Although Switzerland had abstained in the UNGA request for an advisory opinion, it shifted its position once the resolution was passed; it deferred to the will of the international community as embodied in the UNGA. ${ }^{171}$ Similar motivations informed Sweden's submission in support of the opinion, despite its EU membership. ${ }^{172}$ From their brief statements on the matter, it would seem that these First World States supportive of the Court's jurisdiction respected the Court as an institution of international law. Also, the status of the UNGA was regarded as significant and was seen as being able to straddle the political and legal spheres of international life. In the words of Syria, such First World States also saw the UNGA Emergency Special Session as "an expression of the international community". ${ }^{173}$

61. Two academic perspectives about the relative weight to ascribe to ICJ Advisory Opinions illustrate First and Third World perspectives about the nature of international society and international law's place within it. On the one hand, Pomerance has criticized the Court's decision to exercise its jurisdiction in the Wall opinion. She argues that the Court increasingly has come to act under a "duty-to-cooperate" because of its institutional role as the principle judicial organ of the UN. ${ }^{174}$ Pomerance's analysis tries to limit the effect of the Court and the UN more generally in international life: there should be no analogy made between the ICJ and international law or the UN and international society. The ICJ has become a UN Court (rather than a World Court) administering UN law (rather than international law). ${ }^{175}$ Falk, on the other hand, tends to concur with the majority of Third World submissions in support of jurisdiction: the UN request for an advisory opinion was significant and should be respected. Rather than seeing the UN in narrow terms like Pomerance, Falk reminds us that it is "the embodiment of an inchoate organized international community". ${ }^{176}$ Although a number of First World submissions relied on the case of Eastern Carelia to argue that jurisdiction should be declined, Falk reminds us that there was not the same relationship between the PCIJ and the League of Nations as is the case with the UN and the ICJ. ${ }^{177}$ From the UN Charter, “' [j] udicial' needs to be interpreted to encompass not only ... contentious disputes ... but also the role of the Court in declaring and developing international law within the scope of the operations of the UN system". ${ }^{178}$

170 Written Statement of Ireland, above n. 157; Written Statement of Malta (www.icj-cij.org/docket/files/131/ 1623.pdf); Written Statement of Cyprus (www.icj-cij.org/docket/files/131/1617.pdf).

171 Written Submission of Switzerland (www.icj-cij.org/docket/files/131/1577.pdf), paras. 1-6.

172 Written Statement of Sweden (www.icj-cij.org/docket/files/131/1631.pdf).

173 Written Submission of Syria, above n. 114, 2.

174 Michla Pomerance, The ICJ's Advisory Opinion and the Crumbling Wall Between the Political and the Judicial, 99 AJIL (2005), 26, 30.

175 Ibid., 41.

176 Falk, above n. 89, 46, footnote 21.

177 Ibid., 46. Palestine also distinguished the ICJ from the PCIJ by arguing that the ICJ is more explicitly connected to the UN as its principal judicial organ. Written Statement of Palestine, above n. 113, 27, para. 60-61.

178 Falk, above n. 89, 48. Madagascar also advocated greater use of the ICJ advisory function: "Madagascar deplores the under-exploitation of the invaluable resource represented by the advisory procedure". Mr Alfred Rambeloson, Oral Pleading of Madagascar, CR 2004/4, 20. 
Professor Crawford's oral statement for Palestine supported these sentiments, arguing that the Court does "not give just another political opinion". ${ }^{179}$ Instead, it offers a legal opinion sufficiently autonomous and distinct from international political life to act as an "authoritative" 180 source of regulation and legitimacy. ${ }^{181}$

62. Submissions seeking the Court's jurisdiction are indicative of broader faith and reliance on not only the ICJ, but also international law itself. Various Third World submissions made a connection between the UN's long involvement with the Palestinian cause, as well as self-determination more generally, to advance their claims about the central role of its principal judicial organ, the ICJ. Arab States in particular regarded the case to be of singular importance in affirming their faith in international law. Saudi Arabia was optimistic about the effects of an opinion in quelling violence from both sides, stating that an opinion "may give hope that the rule of law will be respected". ${ }^{182}$ For Palestine itself, the stakes were much higher. Mr Al-Kidwa, Palestine's representative at the UN, and its first speaker in the pleadings, stated that if the wall's construction and self-determination's denial continued, it would "destroy [the Palestinians'] faith in the rule of international law and the international community's ability to uphold it in the face of such grievous violations". ${ }^{183}$ Palestine's position and its support by Arab States required that the ICJ, the UN and international law play central roles in the particular issues of the wall as well as the Arab-Israeli conflict. As was the case regarding the protection of Holy Sites in the Occupied Palestinian Territories, ${ }^{184}$ Arab States regarded the Advisory Opinion as being about more than legal doctrine or political negotiations; the case was a test of their faith in international law itself.

\section{V.II. Conclusion}

63. This article has argued that States and inter-governmental organizations can participate in legal pleadings with very different perspectives about international law's strategic qualities as well as its substantive content. The ways in which language was used provided some

179 Professor James Crawford, Oral Statement of Palestine, CR 2004/1, 33, para. 33.

180 Oral Statement of Malaysia, CR 2004/4, 23.

181 Belize regards the ICJ and international law in similar terms: "The law is clearly a reflection of politics and its role as a social regulator is rooted in a reality that is at once political, economic and social, since it would otherwise be nothing. The Court is therefore acting quite logically when it detaches the legal aspects from their broader context, as it must do in the present case." Professor Jean-Marc Sorel, Oral Pleading of Belize, CR 2004/3, 17, para. 13 .

182 Ambasador Fawzi A.Shubokshi, Oral Statement of Saudi Arabia, CR 2004/2, 54.

183 Mr. M. Nasser Al-Kidwa, Oral Statement of Palestine, CR 2004/1, 24.

184 Arab States in particular as well as some other submissions highlighted the importance of preserving Christian, Jewish and Muslim Holy Sites for all worshippers in Jerusalem. For example, see Sir Arthur Watts, Oral Statement of Jordan, CR 2004/4, 56, para. 8; Written Submission of Palestine, above n. 113, 74, para. 174; Written Submission of Morocco, above n. 110, 8; Oral Statement of Saudi Arabia, CR 2004/2, 58-59, para. 55; Written Submission of Sweden, above n. 172, para. 11; Oral Statement of Bangladesh, CR 2004/2, 64; Oral Statement of the League of Arab States, CR 2004/5, 31. The Court (in relative terms) devoted quite a lot of attention to this issue in its judgment as well: ICJ Reports 2004, 136, para. 129. 
indication about the relative importance that States placed on emotive discourse compared with legal terminology. The article has shown that Third World, and especially Arab, States were more comfortable in stretching international legal language across the boundaries of standard "neutral" and non-emotional discourse. This was reinforced by the way in which such States spoke openly about their trust in international law; international law was about more than legal doctrine, it also required a level of faith from the proceedings' participants who tended to place more weight on general principles about self-determination and conquest. The scope of international law was extended further in the accounts of various Arab submissions and the Separate Opinion of Judge Elaraby. Arab sensitivities about history's relevance in present legal matters provided a more contextual narrative about the case. Images of colonialism in the past and in the present also tended to reinforce TWAIL I perspectives that are supportive of modern international law's emancipatory potential for non-European peoples.

64. The ways in which participants participated in the case and the positions taken on the Court's jurisdiction provide useful indications about the relative respect such States placed not only in the ICJ, but also international law. Third World States tended to demonstrate greater reverence for the Court and its formal function. At the same time, however, they supported the work of the UNGA and viewed the resolution requesting an Advisory Opinion as indicative of international public opinion. Thus, the spheres of international politics and international law were distinguished in such submissions, but were also seen as interdependent and inclusive of Third World States. For First World States unsupportive of the Court's jurisdiction, international law tended to garner more formal engagement, as evidenced by less inflammatory language. International law was regarded as being of only limited use in international life. The broader goals discussed by Third World States, such as self-determination and bringing an end to colonialism, were overlooked in most First World submissions and negotiations were contrasted with international law to indicate a clear demarcation between legal and political spheres.

65. Reactions to the Wall Opinion were diverse and varied. Unsurprisingly, Palestine and Israel maintained their earlier positions before the Court. According to Palestine's representative at the UN:

As for the Palestinian people, the advisory opinion has been having a positive - not a negative - impact on Palestinian society. People are seeing that international law can bring them justice. As a result, the law and compliance with it will take in even more importance and prominence within this society. This will be instrumental in developing and ingraining a culture of respect for the law ... this advisory opinion provides a tremendous lesson on the primacy of the law and its rules, and everyone, especially in the region, must see this. ${ }^{185}$ 
66. Israel's representative, on the other hand, argued that:

a disservice was done by the [General] Assembly not just to the International Court of Justice but to the balanced and non-selective application of the rule of law.... The reputation and credibility of international judicial institutions are the worse for it. ${ }^{186}$

67. The Court negotiated a path through these positions to render its judgment, which included as much as it omitted. As in the case of Third World submissions, the ICJ showed that international law could play a role in even the most divisive of issues. To bolster its jurisdiction, as well as its contribution to the conflict, however, the Court found it necessary to retreat behind its doctrinal defences. In its Opinion, the Court employed familiar devices of separating law from politics: the dispute was sufficiently legal; norm conflict was downplayed; language was neutral and historical legacies were reduced to their most minimal and least political form.

68. Post-colonial States were comfortable operating in this discursive environment, but their strategic and substantive positions did not simply mimic the tone of the Court. Instead, Third World, and especially Arab, States used the Advisory Opinion to expand the Court's legal lexicon. These States maintained a faith in international law through the ICJ advisory jurisdiction, and also placed the proceedings in a broader context by resorting to historical narratives and emotive discourse. The Court did not respond to most of these devices, but it is significant that they were used in this forum. Noteworthy as well was the fact that both the Court and Third World States displayed a belief that international law could play a role in the conflict. Agreement over the centrality of self-determination and conquest indicated that both post-colonial States and the Court were in sympathy about the territorial confines of contemporary international law. International legal personality is the sine qua non for Third World States, who in coming to the Peace Palace, confirmed their support and acceptance for the Court and much of the law it applies.

186 Mr. Dan Gillerman, UN representative of Israel, UN GA Emergency Special Session, $27^{\text {th }} \mathrm{mtg}\left(20^{\text {th }}\right.$ July, 2004), UN Doc A/ES-10/PV.27, 7. 